\title{
Fungal glucuronoyl esterases : Genome mining based enzyme discovery and biochemical characterization
}

\section{Dilokpimol, Adiphol}

2018-01-25

Dilokpimol , A, Makela , M R, Cerullo, G, Zhou, M , Varriale , S, Gidijala , L, Bras , J L A , Jutten , P , Piechot , A, Verhaert , R, Faraco , V , Hilden, K S \& de Vries , R P 2018 , ' Fungal glucuronoyl esterases : Genome mining based enzyme discovery and biochemical characterization ' , New Biotechnology , vol. 40, Part B , pp. 282-287 . https://doi.org/10.1016/j.nbt.2017.10.003

http://hdl.handle.net/10138/307189

https://doi.org/10.1016/j.nbt.2017.10.003

acceptedVersion

Downloaded from Helda, University of Helsinki institutional repository.

This is an electronic reprint of the original article.

This reprint may differ from the original in pagination and typographic detail.

Please cite the original version. 
1 Fungal glucuronoyl esterases: genome mining based enzyme discovery and biochemical

2 characterization

4 Adiphol Dilokpimol ${ }^{\mathrm{a}, 1}$, Miia R. Mäkeläb ${ }^{\mathrm{b}, 1}$, Gabriella Cerullo ${ }^{\mathrm{c}, 1}$, Miaomiao Zhou ${ }^{\mathrm{a}, \mathrm{g}}$, Simona

5 Varriale ${ }^{c}$, Loknath Gidijala ${ }^{\text {d }}$, Joana L.A. Brás ${ }^{\mathrm{e}}$, Peter Jütten ${ }^{\mathrm{f}}$, Alexander Piechot ${ }^{\mathrm{f}}$,

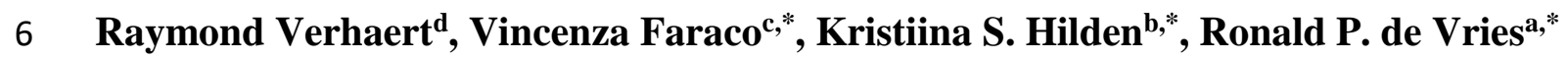

$8 \quad$ a Fungal Physiology, Westerdijk Fungal Biodiversity Institute \& Fungal Molecular Physiology,

9 Utrecht University, Uppsalalaan 8, 3584 CT Utrecht, The Netherlands

10 bivision of Microbiology and Biotechnology, Department of Food and Environmental Sciences,

11 University of Helsinki, Helsinki, Finland

12 'Department of Chemical Sciences, University of Naples "Federico II", Complesso Universitario

13 Monte S. Angelo Via Cintia, 4 IT-80126, Naples, Italy

14 dProteoNic B.V., J.H. Oortweg 19-21, 2333 CH Leiden, The Netherlands

15 eNZYTech B.V., Estrada do Paço do Lumiar, Campus do Lumiar, Edifício E - $1^{\text {o }}$ andar, 1649-

16038 Lisboa, Portugal

17 f Taros Chemicals GmbH \& Co. KG, Emil-Figge-Str. 76a, 44227 Dortmund, Germany

18 gCurrent address: Academie voor de Technologie van Gezondheid en Milieu, Avans Hogeschool, 19 Lovensdijkstraat 61, 4818 AJ Breda, The Netherlands

20

21 *Corresponding authors.

22 E-mail addresses: r.devries@westerdijkinstitute.nl (R.P. de Vries), kristiina.s.hilden@helsinki.fi

23 (K.S. Hilden); vincenza.faraco@unina.it (V. Faraco). 
$24 \quad{ }^{1}$ Equal contribution.

\section{Abstract}

27 4-O-methyl-D-glucuronic acid (MeGlcA) is a side-residue of glucuronoarabinoxylan and can form ester linkages to lignin, contributing significantly to the strength and rigidity of the plant cell wall.

29 Glucuronoyl esterases (4-O-methyl-glucuronoyl methylesterases, GEs) can cleave this ester bond, and therefore may play a significant role as an auxiliary enzyme in biomass saccharification for

31 the production of biofuels and biochemicals. GEs belong to a relatively new family of carbohydrate 32 esterases (CE15) in the CAZy database (www.cazy.org), and so far around ten fungal GEs have 33 been characterized. To explore additional GE enzymes, we used a genome mining strategy. 34 BLAST analysis with characterized GEs against approximately 250 publicly accessible fungal genomes identified more than 150 putative fungal GEs, which were classified into eight phylogenetic sub-groups. To validate the genome mining strategy, 21 selected GEs from both ascomycete and basidiomycete fungi were heterologously produced in Pichia pastoris. Of these enzymes, 18 were active against benzyl D-glucuronate demonstrating the suitability of our genome 39 mining strategy for enzyme discovery.

\section{$41 \quad$ Highlights}

- Over 150 putative fungal GEs were identified by genome mining

- Putative fungal GEs were classified into 8 phylogenetic sub-groups

- New ascomycete and basidiomycete fungal GEs were produced in Pichia pastoris

- Several of the GEs showed very high activity

- New GEs showed potential in plant biomass processing applications 


\section{$48 \quad$ Keywords (4-6 words)}

49 Glucuronoyl esterase, glucuronic acid, genome mining, plant cell wall, fungi

50

\section{Abbreviations}

52 CE, carbohydrate esterase; GE, glucuronoyl esterase.

53

\section{$54 \quad$ Introduction}

55 4-O-methyl-D-glucuronic acid (MeGlcA) is a side-residue of xylan ( $\beta$-1,4-linked $\mathrm{D}$-xylose) that is

56 found in both glucuronoxylan and glucuronoarabinoxylan, which are the principle components

57 present in the secondary cell walls of eudicotyledonous plants and both cell wall layers of 58 commelinoid monocots, respectively (Fig. 1) [1-3]. A large proportion of MeGlcA in xylan can

59 form ester linkages to lignin alcohol; for example $30 \%$ and $40 \%$ of MeGlcA are esterified to lignin

60 in beechwood and birchwood, respectively $[4,5]$. In nature, these lignin-carbohydrate complexes

61 (LCCs) contribute significantly to the strength and rigidity of the plant cell wall rendering it

62 recalcitrant to digestion. However, they impede the industrial applications of plant biomass by

63 restricting the removal of lignin e.g. from cellulosic pulp in pulping processes and hindering

64 efficient enzymatic hydrolysis of biomass in bioethanol production [6-9].

65 Glucuronoyl esterases (4-O-methyl-glucuronoyl methylesterases, GEs) can cleave the ester bond

66 between MeGlcA and lignin, and therefore may play a significant role as auxiliary enzymes in

67 biomass saccharification for the production of biofuels and biochemicals. The first GE was

68 reported in 2006 from a white-rot like fungus Schizophyllum commune [10], and belongs to 


\section{$87 \quad$ Materials and methods}

\section{Bioinformatics}

carbohydrate esterase family 15 (CE15) in the CAZy database [11, 12]. From 182 members in CE15, only 21 are from fungi, and of these so far only around 10 GEs have been characterized (Table 1). Among these, the structures of the Trichoderma reesei (Hypocrea jecorina) Cip2 [13] and the Myceliophthora thermophila (Sporotrichum thermophile) StGE2 [14] have been resolved by X-ray crystallography. The first structure revealed the Ser-His-Glu as the putative catalytic triad of GEs, whereas in the latter case the catalytic serine mutant in complex with methyl 4-O-methyl$\beta$-D-glucopyranuronate was also reported revealing substrate binding within the active site and indicating possible catalytic mechanism of GEs.

In 2014, a European Union (EU) collaborative project 'Optimized esterase biocatalysts for costeffective industrial production' (OPTIBIOCAT, www.optibiocat.eu) was granted by $7^{\text {th }}$ Framework Programme (FP7), which aims to replace chemical processes by enzymatic bioconversion via transesterification of esterases such as GEs for the production of cosmetics. To explore additional fungal GE enzymes, we used a genome mining analysis towards approximately 250 publicly accessible fungal genomes [15]. In this study, we report the genome mining strategy to identify novel fungal GEs and verify the strategy by biochemical characterization of the heterologously produced selected GEs, from both ascomycete and basidiomycete fungi, representing different phylogenetic sub-groups.

Genome mining was performed by BLASTP search against 247 published fungal genomes [15] using 15 amino acid sequences from characterized and putative GEs (A.1, A.2 in Supplementary materials). All resulting amino acid sequences with an expected value lower than $1 \mathrm{E}^{-40}$ were 
92 collected. Duplicate, unusually long and incomplete sequences as well as sequences with

93 ambiguous amino acids (X) were discarded. Signal peptides were predicted using SignalP 4.1

94 (http://www.cbs.dtu.dk/services/SignalP/ [16]) and removed from all candidate sequences. The

95 sequences were aligned using Multiple Alignment using Fast Fourier Transform (MAFFT) [17].

96 Phylogenetic analysis was performed using the maximal likelihood method with complete deletion

97 of gaps and the Poisson correction distance of substitution rates (statistical support for

98 phylogenetic grouping was estimated by 1000 bootstrap re-samplings) of the Molecular

99 Evolutionary Genetics Analysis (MEGA 7) program [18]. A few feruloyl esterase sequences were

100 included as an outgroup. Theoretical molecular masses and pI values were calculated by ExPASy-

101 ProtParam tool (http://www.expasy.ch/tools/protparam.html [19]).

102

103 Cloning of ge genes

104 The genes encoding the selected GEs without signal peptide were codon optimized and synthesized 105 for expression in P. pastoris by NZYTech (Lisbon, Portugal). The gene products were digested by 106 EcoRI and NotI (Thermo Fisher Scientific), and cloned in frame with $\alpha$-factor secretion signal in 107 pPNic706 (ProteoNic, Leiden, the Netherlands). The obtained plasmids were purified from 108 Escherichia coli DH5a (Invitrogen) transformants selected on Luria Bertani medium 109 supplemented with $50 \mu \mathrm{g} / \mathrm{mL}$ kanamycin, fully sequenced (Macrogen, Amsterdam, the 110 Netherlands), linearised by SalI (Thermo Fisher Scientific), and transformed into P. pastoris strain 111 GS115 his4 according to the manufacturer's recommendation.

112 Ten transformants were selected for the enzyme production screening, which was performed in 96 113 deep-well plates containing $0.8 \mathrm{~mL}$ medium. The selected clones were grown first in buffered 114 minimal glycerol medium (1\% yeast nitrogen base, $0.1 \mathrm{M}$ potassium phosphate buffer $\mathrm{pH} 6.5$, and 
$1151 \% \mathrm{w} / \mathrm{v}$ glycerol). The plates were sealed with AeraSeal ${ }^{\mathrm{TM}}$ (Sigma Aldrich) and were incubated

overnight at $30^{\circ} \mathrm{C}, 900 \mathrm{rpm}$ (INFORS HT Microtron, Bottmingen, Switzerland). A volume of cells equal to an $\mathrm{OD}_{600}$ of 1.0 was harvested and resuspended in $0.8 \mathrm{~mL}$ buffered minimal methanol medium ( $1 \%$ yeast nitrogen base, $0.1 \mathrm{M}$ potassium phosphate buffer $\mathrm{pH} 6.5$, and $0.5 \%$ methanol) for induction. The induction was done at $30^{\circ} \mathrm{C}, 900 \mathrm{rpm}$ for $72 \mathrm{~h}$ before being harvested. The cultures were supplemented with $80 \mu \mathrm{L}$ of $0.5 \%$ (v/v) methanol every $24 \mathrm{~h}$.

\section{Production and biochemical properties of recombinant GEs}

P. pastoris transformants were grown according to [20]. Induction was continued for $96 \mathrm{~h}$ at $28^{\circ} \mathrm{C}$ with methanol being supplemented to $0.5 \%$ (v/v) every $24 \mathrm{~h}$. Culture supernatants were harvested (4000 $\left.\times \mathrm{g}, 4^{\circ} \mathrm{C}, 20 \mathrm{~min}\right)$, filtered $(0.22 \mu \mathrm{m}$; Merck Millipore, Darmstadt, Germany) or concentrated (10 kDa cut off; Merck Millipore) and stored at $-20^{\circ} \mathrm{C}$ prior further analysis. Molecular mass determination and deglycosylation were performed as previously described [20]. Protein concentrations were assessed from SDS-PAGE gels by densitometry method using ImageJ program [21] with bovine serum albumin (Pierce, Thermo Scientific) as standard.

\section{Enzyme activity assay of GEs}

Activity of the recombinant GEs towards benzyl D-glucuronate (Taros Chemicals, Dortmund, Germany) was performed in $200 \mu \mathrm{L}$ reaction mixtures adapted from [22]. The reactions were performed in the presence of $2 \mathrm{mM}$ substrate, $73 \mathrm{mM}$ phosphate buffer, $\mathrm{pH} 6.0$, and $50 \mu \mathrm{L}$ of culture supernatant at $45^{\circ} \mathrm{C}$ for $30 \mathrm{~min}$. Detection of glucuronic acid release was performed by using D-Glucuronic/D-Galacturonic Acid Assay Kit (Megazyme, Wicklow, Ireland) according to the manufacturer's recommendation. The culture supernatant of $P$. pastoris harboring pPNic706 
138 plasmid without insert was used as negative control. All assays were performed in triplicate. One

139 unit was defined as the amount of enzyme de-esterifying $1 \mu \mathrm{mol}$ of benzyl-D-glucuronic acid ester

140 per min under the assay conditions.

\section{Results and discussion}

143 Genome mining and phylogenetic analysis of novel fungal GES

144 To identify the putative fungal GEs, a genome mining strategy was conducted by BLAST analysis 145 with characterized and putative GEs against the published fungal genomes [15]. More than 150 146 putative fungal GEs were identified, which can be classified into 8 phylogenetic sub-groups (Fig.

147 2, A.1, A.2 in Supplementary materials). The first characterized GE (S. commune, ScGE, [10, 23])

148 located to Sub-group 4 together with GEs from the white-rot fungi Phanerochaete carnosa 149 (PcGCE, [24]), Phanerochaete chrysosporium (PcGE1, PcGE2; [25]) and Cerrena unicolor 150 (CuGE, [26]) (Fig. 2). The ascomycete GEs, Trichoderma reesei GE (Cip2, [12]) and Podospora 151 anserina GE (PaGE1, [27]) clustered in Sub-group 5. Sub-group 8 consisted of the GEs from the 152 ascomycete fungi Myceliophthora thermophila (StGE1, [28]) and Neurospora crassa (NcGE, 153 [29]), whereas Sub-group 1 consisted of a second GE from M. thermophila (StGE2, [30]). No 154 characterized GE belongs to Sub-group 2, 3, 6 and 7. Sub-group 3 consists of more than 30 155 members and Sub-group 7 consists of 15 members, whereas Sub-group 2 and 6 are small sub156 groups containing 3-4 GE candidates. One GE candidate from an anaerobic fungus Piromyces sp. 157 E2 (PirGE1) did not locate to any of the sub-groups. This ungrouped sequence may develop into 158 a new sub-group if homologs for it are discovered. Two characterized bacterial GEs were included 159 in the analysis, and clustered separately from the fungal GEs (Fig. 2). 
160 Recently, a new classification of GEs was reported based on peptide pattern recognition (PPR) 161 [31], which separate putative GEs into 24 PPR groups. Fungal GEs were clustered in PPR groups

1621,8 , and 18. In comparison to our phylogenetic classification, the members from PPR group 8 163 belonged to phylogenetic Sub-group 1, whereas the members from PPR group 1 were divided in 164 different phylogenetic groups. PPR group 18 contained only one member (GenBank 165 XP_001832002.2 from Coprinopsis cinerea) representing an unusually long sequence (containing 1663438 amino acids), hence it was not included in our phylogenetic analysis. In addition, a new 167 database for Carboxylic Ester Hydrolases (CEH) was launched - CASTLE (CArboxylic eSTer 168 hydrolase, http://castle.cbe.iastate.edu/, Iowa State University [32]). However, GEs are currently 169 grouped together with acetyl xylan esterases in CEH8 in CASTLE database.

171 Sequence analysis and catalytic triad of selected fungal GES

172 Twenty-one candidates (five characterized and 16 putative fungal GEs) were selected from both 173 ascomycete and basidiomycete fungi with focus on wood rotting fungi (e.g. Dichomitus squalens, $174 P$. carnosa, Schizophyllum commune, Stereum hirsutum), saprophytic fungi living on dead plant 175 or herbivore dung (e.g. Podospora anserina, Ascobolus immersus, Apiospora montagnei), plant 176 pathogens (e.g. Botryosphaeria dothidea, Stagonospora nodorum, Leptosphaeria maculans) as 177 well as industrially exploited fungi (e.g. T. reesei, Penicillium rubens), covering all eight sub178 groups from the phylogenetic tree, including one ungrouped sequence (PirGE1), for heterologous 179 production using $P$. pastoris as a host and subsequent biochemical characterization (Table 2). The 180 selection of the number of putative GEs was solely based on the size of the phylogenetic sub181 group. The amino acid sequence alignment of 16 putative fungal GEs and all characterized GEs 182 are present in A.3 in Supplementary materials. The fungal GEs were relatively conserved and the 
183 signature motif of CE15 family (G-C-S-R-X-G, [30]) was well aligned, except for PirGE1 which 184 has Tyr instead of Arg. In addition, two bacterial GEs (CesA and MZ0003) have Val and His, 185 respectively, instead of Cys in the signature motif. Among the catalytic triad, Ser and His are well 186 conserved in all sequences, whereas Glu is not very conserved among CE15 enzymes and is 187 substituted by Asp, Gln, Asn and Ala, as well as Ser (StGE2, PaGE2 - Podospora anserina, 188 DsGE1 - Dichomitus squalens) and Cys (LmGE1 - Leptosphaeria maculans, CesA and MZ0003) $189[33]$.

191 Biochemical properties of selected fungal GEs

192 The putative GE-encoding genes were heterologously expressed in P. pastoris. Only two (PaGE2 193 and AbGE1 - Agaricus bisporus) out of 21 GE candidates were not successfully produced. The 194 production level varied from 2-336 mg/L, and four enzymes (HsGE1 - Hypholoma sublateritium, 195 PcGCE, Cip2, ShGE1 - Stereum hirsutum) were produced up to $300 \mathrm{mg} / \mathrm{L}$. From the 19 produced 196 GE candidates, 18 were active towards benzyl-D-glucuronic acid ester (Table 2). The highest 197 specific activity (>1,000 nkat/mg) was detected for PcGCE, HsGE1 and DsGE1. SnGE1 198 Stagonospora nodorum and LmGE1 showed low activity (0.156 nkat/ml and $0.097 \mathrm{nkat} / \mathrm{ml}$, 199 respectively) and were produced at low level as they were not visible in Coomassie blue stained 200 SDS-PAGE gel. CcGE1 protein from Coprinopsis cinerea was highly produced but not active 201 towards the tested substrate on different $\mathrm{pH}(4-8)$.

203 Conclusions

204 In the present study, we showed that genome mining is a powerful strategy for enzyme discovery 205 to identify fungal GE encoding genes. Our phylogenetical analysis categorized the putative fungal 
GEs into eight sub-groups. We further demonstrated that from 16 putative fungal GEs, 13 possessed GE activity towards benzyl D-glucuronate. The members from Sub-groups 1, 4, 5 and 8 were previously characterized and shown to possess GE activity (Table 1). Here we demonstrated that the candidates from Sub-groups 3, 6, and 7 also possessed GE activity (Table 2). Because of the limited availability of substrates used for the assessment of GE activity, currently it is not possible to verify if the phylogenetical grouping also reflects functional differences among GEs, such as substrate specificity or possible site of action.

In comparison with the previously characterized fungal GEs used in this study, most of the new GEs showed comparable activity. This indicates that they may have potential in saccharification of plant biomass or other industrial applications.

Funding This work was supported by the European Union, Grant agreement no: 613868 (OPTIBIOCAT).

\section{Acknowledgments}

The authors would like to thank Prof. Paul Christakopoulos (Luleå University of Technology, Sweden) for providing the glucuronoyl esterase assay method.

\section{Appendix A. Supplementary data}

A.1 Phylogenetic tree of the (putative) fungal GEs. $\triangle$, characterized GEs. The sequences used for BLASTP search in genome mining analysis are indicated as $\diamond$ for characterized GEs and $\bigcirc$ for putative GEs. Filled symbols indicate selected GEs for characterization in the present study. Bact. 
230 indicates group of bacterial GEs. U indicates ungrouped sequences. Feruloyl esterases (FAEs) 231 were used as an outgroup. The same symbols are used in Fig. 2.

232

233 A.2 Sequences of characterized and putative GEs used in the present study. Protein families (Pfam) 234 and carbohydrate binding motifs (CBM) were predicted using MOTIF Search tool from 235 GenomeNet (http://www.genome.jp/tools/motif/, Bioinformatics Center - Kyoto University). 236 Selected GEs for characterization in the present study are marked in light blue.

237

238 A.3 Amino acid sequence alignment of characterized and selected GEs (full names of the enzymes 239 are given in Tables 1 and 2). The sequence alignment was performed using Multiple Alignment 240 using Fast Fourier Transform (MAFFT) [17] and visualized using Easy Sequencing in Postscript 241 (ESPript - http://espript.ibcp.fr, [34]). The structures of Hypocrea jecorina Cip2 (3PIC, [13]) were 242 used as a secondary structure depiction. $\nabla$ indicates catalytic residues. 


\section{References}

245 [1] York WS, O’Neill MA. Biochemical control of xylan biosynthesis — which end is up? Curr 246 Opin Plant Biol 2008;11:258-265.

247 [2] Scheller HV, Ulvskov P. Hemicelluloses. Annu Rev Plant Biol 2010;61:263-289.

248 [3] Ebringerová A. Structural diversity and application potential of hemicelluloses. Macromol 249 Symp 2005;232:1-12.

250 [4] Takahashi N, Koshijima T. Molecular properties of lignin-carbohydrate complexes from 251 beech (Fagus crenata) and pine (Pinus densiflora) woods. Wood Sci and Technol 1988;22:177252189.

253 [5] Watanabe T, Koshijima T. Evidence for an ester linkage between lignin and glucuronic acid 254 in lignin-carbohydrate complexes by DDQ-Oxidation. Agric Biol Chem 1988;52:2953-2955. 255 [6] Koshijima T, Watanabe T. Association between lignin and carbohydrates in wood and other 256 plant tissues, Springer Berlin Heidelberg 2003.

257 [7] Várnai A, Siika-aho M, Viikari L. Restriction of the enzymatic hydrolysis of steam-pretreated 258 spruce by lignin and hemicellulose. Enzyme Microb Technol 2010;46:185-193.

259 [8] Himmel ME, Ding S-Y, Johnson DK, Adney WS, Nimlos MR, Brady JW, et al. Biomass 260 recalcitrance: Engineering plants and enzymes for biofuels production. Science 2007;315:804261807.

262 [9] Min D-y, Yang C, Chiang V, Jameel H, Chang H-m. The influence of lignin-carbohydrate 263 complexes on the cellulase-mediated saccharification II: Transgenic hybrid poplars (Populus 264 nigra L. and Populus maximowiczii A.). Fuel 2014;116:56-62.

265 [10] Špániková S, Biely P. Glucuronoyl esterase - Novel carbohydrate esterase produced by 266 Schizophyllum commune. FEBS Lett 2006;580:4597-4601. 
267 [11] Lombard V, Golaconda Ramulu H, Drula E, Coutinho PM, Henrissat B. The carbohydrate268 active enzymes database (CAZy) in 2013. Nucleic Acids Res 2014;42:D490-D495.

269 [12] Li X-L, Špániková S, de Vries RP, Biely P. Identification of genes encoding microbial 270 glucuronoyl esterases. FEBS Lett 2007;581:4029-4035.

271 [13] Pokkuluri PR, Duke NEC, Wood SJ, Cotta MA, Li X-L, Biely P, et al. Structure of the 272 catalytic domain of glucuronoyl esterase Cip2 from Hypocrea jecorina. Proteins: Struct, Funct, 273 Bioinf 2011;79:2588-2592.

274 [14] Charavgi MD, Dimarogona M, Topakas E, Christakopoulos P, Chrysina ED. The structure 275 of a novel glucuronoyl esterase from Myceliophthora thermophila gives new insights into its role 276 as a potential biocatalyst. Acta Crystallogr Sect D-Biol Crystallogr 2013;69:63-73.

277 [15] Dilokpimol A, Mäkelä MR, Aguilar-Pontes MV, Benoit-Gelber I, Hildén KS, de Vries RP. 278 Diversity of fungal feruloyl esterases: updated phylogenetic classification, properties, and 279 industrial applications. Biotechnol Biofuels 2016;9:231.

280 [16] Petersen TN, Brunak S, von Heijne G, Nielsen H. SignalP 4.0: discriminating signal 281 peptides from transmembrane regions. Nat Meth 2011;8:785-786.

282 [17] Katoh K, Standley DM. MAFFT multiple sequence alignment software version 7:

283 improvements in performance and usability. Mol Biol Evol 2013;30:772-780.

284 [18] Kumar S, Stecher G, Tamura K. MEGA7: Molecular Evolutionary Genetics Analysis 285 version 7.0 for bigger datasets. Mol Biol Evol 2016;33:1887.

286 [19] Gasteiger E, Hoogland C, Gattiker A, Duvaud S, Wilkins MR, Appel RD, et al. Protein 287 identification and analysis tools on the ExPASy Server. In: Walker JM (editor). The proteomics 288 protocols handbook, Totowa, NJ: Humana Press; 2005, p. 571-607. 
289 [20] Dilokpimol A, Mäkelä MR, Mansouri S, Belova O, Waterstraat M, Bunzel M, et al.

290 Expanding the feruloyl esterase gene family of Aspergillus niger by characterization of a feruloyl

291 esterase, FaeC. N Biotechnol 2017;37, Part B:200-209.

292 [21] Schneider CA, Rasband WS, Eliceiri KW. NIH Image to ImageJ: 25 years of image

293 analysis. Nat Meth 2012;9:671-675.

294 [22] Sunner H, Charavgi M-D, Olsson L, Topakas E, Christakopoulos P. Glucuronoyl esterase 295 screening and characterization assays utilizing commercially available benzyl glucuronic acid 296 ester. Molecules 2015;20:17807.

297 [23] Wong DWS, Chan VJ, McCormack AA, Hirsch J, Biely P. Functional cloning and 298 expression of the Schizophyllum commune glucuronoyl esterase gene and characterization of the 299 recombinant enzyme. Biotechnol Res Int 2012;2012:951267.

300 [24] Tsai AYL, Canam T, Gorzsás A, Mellerowicz EJ, Campbell MM, Master ER. Constitutive 301 expression of a fungal glucuronoyl esterase in Arabidopsis reveals altered cell wall composition 302 and structure. Plant Biotech J 2012;10:1077-1087.

303 [25] Duranová M, Hirsch J, Kolenová K, Biely P. Fungal glucuronoyl esterases and substrate 304 uronic acid recognition. Biosci Biotechnol Biochem 2009;73:2483-2487.

305 [26] d'Errico C, Jørgensen JO, Krogh KBRM, Spodsberg N, Madsen R, Monrad RN. Enzymatic 306 degradation of lignin-carbohydrate complexes (LCCs): Model studies using a fungal glucuronoyl 307 esterase from Cerrena unicolor. Biotechnol Bioeng 2015;112:914-922.

308 [27] Katsimpouras C, Bénarouche A, Navarro D, Karpusas M, Dimarogona M, Berrin J-G, et al. 309 Enzymatic synthesis of model substrates recognized by glucuronoyl esterases from Podospora 310 anserina and Myceliophthora thermophila. Appl Microbiol Biotechnol 2014;98:5507-5516. 
311 [28] Vafiadi C, Topakas E, Biely P, Christakopoulos P. Purification, characterization and mass

312 spectrometric sequencing of a thermophilic glucuronoyl esterase from Sporotrichum

313 thermophile. FEMS Microbiol Lett 2009;296:178-184.

314 [29] Huynh HH, Arioka M. Functional expression and characterization of a glucuronoyl esterase

315 from the fungus Neurospora crassa: identification of novel consensus sequences containing the

316 catalytic triad. J Gen Appl Microbiol 2016;87:1765-1772.

317 [30] Topakas E, Moukouli M, Dimarogona M, Vafiadi C, Christakopoulos P. Functional

318 expression of a thermophilic glucuronoyl esterase from Sporotrichum thermophile: identification

319 of the nucleophilic serine. Appl Microbiol Biotechnol 2010;87:1765-1772.

320 [31] Agger JW, Busk PK, Pilgaard B, Meyer AS, Lange L. A new functional classification of

321 glucuronoyl esterases by Peptide Pattern Recognition. Front Microbiol. 2017;8:309.

322 [32] Chen Y, Black DS, Reilly PJ. Carboxylic ester hydrolases: Classification and database

323 derived from their primary, secondary, and tertiary structures. Protein Sci 2016;25:1942-1953.

324 [33] De Santi C, Willassen NP, Williamson A. Biochemical characterization of a family 15

325 carbohydrate esterase from a bacterial marine arctic metagenome. PLoS One 2016;11:e0159345.

326 [34] Robert X, Gouet P. Deciphering key features in protein structures with the new ENDscript

327 server. Nucleic Acids Res 2014;42:W320-W324.

328 [35] Hüttner S, Klaubauf S, de Vries RP, Olsson L. Characterisation of three fungal glucuronoyl

329 esterases on glucuronic acid ester model compounds. Appl Microbiol Biotechnol 2017;

$330 \quad 101: 5301-5311$.

331 [36] Biely P, Malovíková A, Uhliariková I, Li X-L, Wong DWS. Glucuronoyl esterases are

332 active on the polymeric substrate methyl esterified glucuronoxylan. FEBS Lett 2015;589:2334-

3332339. 


\section{$335 \quad$ Figure captions}

336 Fig. 1 Model structure of 4- $O$-methyl-D-glucurono(arabino)xylan [modified from 12, 15]. GE

337 indicates glucuronoyl esterase. In nature *O is typically linked to lignin instead of methyl group.

339 Fig. 2 Phylogenetic relationships among the (putative) fungal GEs. $\triangle$, characterized GEs. The 340 sequences used for BLASTP search in genome mining analysis are indicated as $\diamond$ for 341 characterized GE and $\bigcirc$ for putative GEs. Filled symbols indicate selected GEs for 342 characterization in the present study. Bact. indicates group of bacterial GEs. U indicates ungrouped 343 sequences. Feruloyl esterases (FAEs) were used as an outgroup. Full phylogenetic tree is given in 344 A.1 in Supplementary materials. Full enzyme names, details and sequences are given in Table 2 345 and A.2 in Supplementary materials. 
Table 1 Characterized GEs with their properties

\begin{tabular}{|c|c|c|c|c|c|c|c|c|c|c|}
\hline \multirow{2}{*}{ Origin } & \multirow{2}{*}{ Enzyme } & \multirow{2}{*}{$\begin{array}{l}\text { Sub- } \\
\text { group }\end{array}$} & \multirow{2}{*}{ Production $^{a}$} & \multirow{2}{*}{$\begin{array}{c}\text { Molecular } \\
\text { mass } \\
(\mathbf{k D a})^{2}\end{array}$} & \multicolumn{2}{|c|}{ pH } & \multicolumn{2}{|c|}{ Temperature $\left({ }^{\circ} \mathbf{C}\right)$} & \multirow{2}{*}{$\mathbf{p} I^{\mathrm{b}}$} & \multirow{2}{*}{ Reference } \\
\hline & & & & & Optimum & Stability & Optimum & Stability & & \\
\hline \multicolumn{11}{|l|}{ Fungi } \\
\hline Schizophyllum & ScGE & 4 & Pur & 44 & 7.0 & - & 50 & - & 3.5 & {$[10]$} \\
\hline commune & $(\mathrm{rScGE})$ & & HP & $53(42)$ & - & - & - & - & 3.7 & {$[23]$} \\
\hline $\begin{array}{l}\text { Hypocrea jecorina } \\
\text { (Trichoderma } \\
\text { reesei) }\end{array}$ & Cip2 & 5 & HT & 55 & 5.5 & $4.0-8.0$ & $40-60$ & $<40$ & 7.9 & [12] \\
\hline $\begin{array}{l}\text { Phanerochaete } \\
\text { chrysosporium }\end{array}$ & PcGE1 & 4 & $\mathrm{HAv}, \mathrm{Pc}, \mathrm{Sc}$ & 47 & $5.0-6.0$ & - & $45-55$ & - & $6.5(5.5)$ & {$[25,35]$} \\
\hline $\begin{array}{l}\text { Phanerochaete } \\
\text { chrysosporium }\end{array}$ & PcGE2 & 4 & HSc & 42 & $5.0-6.0$ & - & $45-55$ & - & $4.7(4.8)$ & {$[25]$} \\
\hline $\begin{array}{l}\text { Myceliophthora } \\
\text { thermophila } \\
\text { (Sporotrichum } \\
\text { thermophile) }\end{array}$ & StGE1 & 8 & Pur & 58 & 6.0 & $7.0-8.0$ & 60 & $<55$ & 6.7 & {$[28]$} \\
\hline $\begin{array}{l}\text { Myceliophthora } \\
\text { thermophila } \\
\text { (Sporotrichum } \\
\text { thermophile) }\end{array}$ & StGE2 & 1 & $\mathrm{HP}$ & 43 & 7.0 & $4.0-10.0$ & 55 & $<50$ & $(5.8)$ & {$[30]$} \\
\hline $\begin{array}{l}\text { Phanerochaete } \\
\text { carnosa }\end{array}$ & PcGCE & 4 & HP, HAt & $72(42)$ & 6.0 & - & 40 & - & - & {$[24]$} \\
\hline $\begin{array}{l}\text { Podospora } \\
\text { anserina }\end{array}$ & PaGE1 & 5 & HP & 63 & - & - & - & - & $\begin{array}{l}7.6 \text { and } \\
8.2(6.9)\end{array}$ & {$[27]$} \\
\hline Cerrena unicolor & $\mathrm{CuGE}$ & 4 & HAo & $58(48)$ & - & - & - & - & - & {$[26]$} \\
\hline Neurospora crassa & $\mathrm{NcGE}$ & 8 & HP & 44 & 7.0 & $4.0-7.0$ & $40-50$ & $<70$ & - & {$[29]$} \\
\hline $\begin{array}{l}\text { Acremonium } \\
\text { alcalophilum }\end{array}$ & AaGE1 & 5 & HP & $72(53)$ & - & $7.0-11.0$ & - & $<50$ & - & {$[35]$} \\
\hline Wolfiporia cocos & WcGE1 & 4 & $\mathrm{HP}$ & $45(44)$ & - & $7.0^{\mathrm{c}}$ & - & $<40$ & - & {$[35]$} \\
\hline Bacteria & & & & & & & & & & \\
\hline $\begin{array}{l}\text { Ruminococcus } \\
\text { flavefaciens }\end{array}$ & $\operatorname{ces} \mathrm{A}$ & - & $\mathrm{HE}$ & 46 & - & - & - & - & - & {$[36]$} \\
\hline
\end{tabular}


${ }^{a}$ Pur, purified from the original source; H, homologous expression (Ao, Aspergillus oryzae; At, Arabidopsis thaliana, Av, Aspergillus vadensis; E, Escherichia coli; P, Pichia pastoris; Pc, Pycnoporus cinnabarinus; T, Trichoderma reesei; Sc, Schizophyllum commune)

${ }^{\mathrm{b}}$ Parentheses indicate calculated values

${ }^{\mathrm{c}} \mathrm{pH}$ stability varied on the buffer [35] 
Table 2 Molecular mass, production level and specific activity of characterized GEs in this work ${ }^{\mathrm{a}}$.

\begin{tabular}{|c|c|c|c|c|c|c|c|c|c|}
\hline Fungal species & Accession number & $\begin{array}{l}\text { Sub- } \\
\text { group }\end{array}$ & Name $^{b}$ & $\begin{array}{c}\text { Calculated } \\
\text { molecular } \\
\text { mass }(k D a)\end{array}$ & $\begin{array}{r}\text { Apparent } \\
\text { molecular } \\
\text { mass (kDa) }\end{array}$ & $\begin{array}{r}\text { Deglycosylated } \\
\text { protein }(\mathrm{kDa})\end{array}$ & $\begin{array}{r}\text { Calculated } \\
\mathrm{p} I\end{array}$ & $\begin{array}{r}\text { Production } \\
(\mathrm{mg} / \mathrm{L})\end{array}$ & $\begin{array}{r}\text { Relative } \\
\text { activity } \\
\text { (nkat/mg) }\end{array}$ \\
\hline $\begin{array}{l}\text { Podospora } \\
\text { anserina }\end{array}$ & CAP59671 & 1 & PaGE2 & 44.3 & nd & nd & 8.3 & $\mathrm{np}$ & na \\
\hline $\begin{array}{l}\text { Leptosphaeria } \\
\text { maculans }\end{array}$ & CBX90574 & 1 & LmGE1 & 41.6 & nd & nd & 8.2 & $\mathrm{np}$ & Active $^{\mathrm{d}}$ \\
\hline $\begin{array}{l}\text { Dichomitus } \\
\text { squalens }\end{array}$ & jgi|Dicsq1|58498 & 1 & DsGE1 & 41.8 & $65-70$ & 45 & 5.0 & 2 & 1,159 \\
\hline $\begin{array}{l}\text { Coprinopsis } \\
\text { cinerea }\end{array}$ & jgi|Copci1|5044 & 2 & CcGE1 & 43.4 & $60-75$ & 45 & 6.0 & 52 & na \\
\hline $\begin{array}{l}\text { Penicillium } \\
\text { rubens }\end{array}$ & CAP91804 & 3 & $\begin{array}{c}\text { PrGE1 } \\
\text { (Pc13g07350) }\end{array}$ & 40.2 & $50-60$ & 42 & 6.3 & 14 & 162 \\
\hline $\begin{array}{l}\text { Agaricus } \\
\text { bisporus }\end{array}$ & $\begin{array}{l}\text { jgi|Agabi_varbisH9 } \\
7 \_2 \mid 209748\end{array}$ & 3 & AbGE1 & 46.5 & nd & nd & 5.9 & $\mathrm{np}$ & na \\
\hline $\begin{array}{l}\text { Hypholoma } \\
\text { sublateritium }\end{array}$ & jgi|Hypsu1|50423 & 3 & HsGE1 & 47.4 & 48.8 & nd & 5.6 & 336 & 2,334 \\
\hline $\begin{array}{l}\text { Schizophyllum } \\
\text { commune }\end{array}$ & XP_003026289 & 4 & ScGE & 40.2 & 40 & 36 & 4.3 & 25 & 4 \\
\hline $\begin{array}{l}\text { Phanerochaete } \\
\text { carnosa }\end{array}$ & AFM93784 & 4 & PcGCE & 42.5 & nd & nd & 4.6 & 330 & 4,501 \\
\hline $\begin{array}{l}\text { Stereum } \\
\text { hirsutum }\end{array}$ & jgi|Stehi1|96554 & 4 & ShGE1 & 47.2 & nd & nd & 4.6 & 296 & 333 \\
\hline $\begin{array}{l}\text { Dichomitus } \\
\text { squalens }\end{array}$ & jgi|Dicsq1|107426 & 4 & DsGE2 & 46.7 & $75-100$ & 50 & 4.2 & 38 & 46 \\
\hline $\begin{array}{l}\text { Podospora } \\
\text { anserina }\end{array}$ & XP_001903136 & 5 & PaGE1 & 49.2 & 60 & 60 & 8.1 & 26 & 60 \\
\hline $\begin{array}{l}\text { Trichoderma } \\
\text { reesei }\end{array}$ & AAP57749 & 5 & Cip2 & 46.7 & 71.4 & nd & 6.4 & 323 & 333 \\
\hline $\begin{array}{l}\text { Ascobolus } \\
\text { immersus }\end{array}$ & jgi|Ascim1|226781 & 5 & AiGE1 & 47.6 & nd & 45.5 & 7.7 & $<1$ & 225 \\
\hline $\begin{array}{l}\text { Piriformospora } \\
\text { indica }\end{array}$ & CCA74892 & 5 & PiGE1 & 47.9 & nd & 48.9 & 8.3 & 5 & 67 \\
\hline $\begin{array}{l}\text { Botryosphaeria } \\
\text { dothidea }\end{array}$ & jgi|Botdo1|13681 & 6 & BdGE1 & 39.0 & nd & 42.4 & 7.2 & 1 & 77 \\
\hline $\begin{array}{l}\text { Stagonospora } \\
\text { nodorum }\end{array}$ & jgi|Stano2|2908 & 7 & SnGE1 & 39.5 & nd & nd & 7.8 & $\mathrm{np}$ & Active $^{\mathrm{d}}$ \\
\hline $\begin{array}{l}\text { Myceliophthora } \\
\text { thermophila } \\
\text { (Sporotrichum } \\
\text { thermophile) }\end{array}$ & AEO60464.1 & 8 & StGE1 & 40.3 & 40 & 40 & 5.6 & 66 & 31 \\
\hline
\end{tabular}




\begin{tabular}{llllcccc}
$\begin{array}{l}\text { Podospora } \\
\text { anserina }\end{array}$ & CAP65970 & 8 & PaGE3 & 40.3 & $50-60$ & 40 & 8.5 \\
$\begin{array}{l}\text { Apiospora } \\
\text { montagnei }\end{array}$ & jgi|Apimo1|126025 & 8 & AmGE1 & 40.0 & $40-50$ & 64 & 6.7 \\
\hline $\begin{array}{l}\text { Piromyces sp. } \\
\text { E2 }\end{array}$ & jgi|PirE2_1|60981 & U & PirGE1 & 40.6 & 42 & 40 & 6.1
\end{tabular}

${ }^{a}$ nd, not detected; np, not produced; na, not active

${ }^{\mathrm{b}}$ Name in bold indicates the previously reported GEs

${ }^{c}$ The assay performed at $45^{\circ} \mathrm{C}$ using $2 \mathrm{mM}$ benzyl-D-glucuronic acid ester in $73 \mathrm{mM}$ phosphate buffer, $\mathrm{pH} 6.0$

d The enzyme was active but specific activity cannot be calculated because of undetectable protein level on the SDS-PAGE 
Page $\mathbf{2 1}$ of $\mathbf{2 1}$ 